\author{
Danuta Opozda* \\ Lublin
}

\title{
Interdyscyplinarność i intradyscyplinarność w pedagogice rodziny
}

Pedagogiczna wiedza o wychowaniu w rodzinie ma rozległą tradycję, jej źródła sięgają pedagogii wychowania w rodzinie i łączą się z praktyką życia poprzedzająca wiedzę naukową i wykraczają poza dyscyplinarne ramy. Rzeczywistość wychowania w rodzinie, będąc materialnym przedmiotem poznania wielu nauk, staje się jednocześnie przedmiotem formalnym ${ }^{1}$ poszczególnych dyscyplin. Rozwój wiedzy o wychowaniu w rodzinie oznacza jej tworzenie, porządkowanie i systematyzację według wypracowywanych kryteriów naukowości dla danej dziedziny, dyscypliny i subdyscypliny. Pedagogiczna wiedza o wychowaniu w rodzinie subdyscyplinarnie związana była (i jest) z pedagogiką społeczną ${ }^{2}$. Rozwijająca się natomiast $w$ ramach nauk o wychowaniu pedagogika rodziny traktowana jest często przez wielu badaczy jako subdyscyplina in statu nascendi, co niektórzy nota bene uznają za ,jarzmo", niższy poziom zaawansowania i rozwoju subdyscyplinego. Wydaje mi się, że można jednak na kwestię in statu nascendi pedagogiki rodziny spojrzeć jako na szansę, wyraz rozwoju i „dojrzałości” subdyscyplinarnej”.

* Dr hab. Danuta Opozda jest adiunktem w Katedrze Pedagogiki Rodziny w Instytucie Pedagogiki Katolickiego Uniwersytetu Lubelskiego Jana Pawła II.

1 A. Bronk, Czy pedagogika jest naukq autonomicznq?, w: M. Nowak, T. Ożóg, A. Rynio (red.), W trosce o integralne wychowanie, Lublin 2003, s. 57.

${ }^{2}$ D. Opozda Wybrane problemy pedagogiki rodziny jako subdyscypliny pedagogicznej, w: S. Kawula, E. Marynowicz-Hetka, A. Przecławska (red.), Pedagogika społeczna w perspektywie europejskiej. Przeszłość - teraźniejszość - przyszłość, Olsztyn 2003, s. 85-91. 
Złożone zagadnienia rozwoju wiedzy naukowej są podejmowane wieloaspektowo w ramach klasyfikacji i metodologii nauk. Ich analiza implikuje ontologiczne, epistemologiczne, antropologiczne i aksjologiczne konteksty. $\mathrm{W}$ odniesieniu do tych zagadnień istotna jest interdyscyplinarność w uprawianiu naukowej refleksji nad wychowaniem w rodzinie.

Problem interdyscyplinarności zjednej strony oznacza dylematy związane z określeniem subdyscyplinarnego charakteru pedagogiki rodziny, z drugiej, merytorycznie ukierunkowuje na rzeczywistość wychowania w rodzinie jako przedmiot poznania naukowego. Zauważyć też trzeba, że problem inter- i intradyscyplinarności w pedagogice rodziny odnosi się również do ogólnych ustaleń czynionych w tym zakresie na poziomie dyscypliny i na poziomie metodologii nauk. Interdyscyplinarność to w znacznej mierze problem dziedziny nauki, dyscypliny i jej subdyscyplin. Główne rozwiązania, ustalenia, rozstrzygnięcia dokonują się nie tyle na poziomie subdyscyplinarnym, ile na poziomie dyscypliny naukowej. Istniejące w tym zakresie trudności należy też wiązać z metodologicznymi dylematami pedagogiki jako dyscypliny nauki.

W niniejszym artykule podejmuję refleksję nad interdyscyplinarnością i intradyscyplinarnością w pedagogice rodziny, uwzględniając wybrane, ale jak sądzę, ważne aspekty. Refleksja ta jest w pewnym stopniu nawiązaniem do metodologicznych zagadnień pedagogiki rodziny obecnych w literaturze przedmiotu ${ }^{3}$. Jest jednocześnie próbą kontynuacji podejmowanych już przeze mnie kwestii, dotyczących metodologicznych ram rozwoju wiedzy w pedagogice rodziny ${ }^{4}$.

\section{Przejawy problematyczności interdyscyplinarności - rozumienie i pojęcia poboczne}

Lata siedemdziesiąte przyniosły zainteresowanie interdyscyplinarnością (międzydyscyplinarnością) w nauce i zagadnieniami współpracy dyscyplin

${ }^{3}$ Zob. A. Ładyżyński (red.), Pedagogika rodziny - in statu nascendi czy uznana subdyscyplina?, Wrocław 2012; B. Kiereś, M. Nowak, D. Opozda (red.), Wybrane zagadnienia teorii i praktyki pedagogiki rodziny. Pamięci Księdza Profesora Józefa Wilka SDB (1937-2003), Lublin-Kraków 2006; A. W. Janke Próba syntetycznego spojrzenia na rozwój pedagogiki rodziny, w: tenże (red.), Pedagogika rodziny na progu XXI wieku. Rozwój, przedmiot, obszary refleksji i badań, Toruń 2004, s. 345-352.

${ }^{4}$ D. Opozda, Rozwój wiedzy w pedagogice rodziny w kontekście wybranych problemów metodologicznych pedagogiki, w: A. Ładyżyński (red.), dz. cyt., s. 67-89. 
w zakresie rozwoju wiedzy naukowej ${ }^{5}$. Wiedza o wychowaniu w rodzinie łączy się z prowadzoną w naukach społecznych i humanistycznych dyskusją nad problematycznością interdyscyplinarności ${ }^{6}$. Dotyczy to też wprost pedagogiki rodziny z racji szerokiego przedmiotu poznania, jakim jest wychowanie w rodzinie. W dyskusji tej oprócz merytorycznych zagadnień związanych z wyjaśnieniem, rozumieniem, pokazaniem kontekstu interdyscyplinarności pojawiają się różne głosy co do nadużywania i instrumentalnego traktowania samego pojęcia ,interdyscyplinarność".

Interdyscyplinarność jest traktowana w niektórych podejściach i badaniach jak moda czy fanaberia, która w rezultacie przeminie, albo jak stała zasada, coś oczywistego, co jest popularne i automatyczne, co stało się ,,alibi” i truizmem. W związku z tym można uznać, że interdyscyplinarność jest zagrożona banalizacją i pozorem, jest nadużywana ${ }^{7}$. Bywa, że interdyscyplinarnością nazywa się coś, co stanowi raczej sumowanie treści i poglądów różnych dyscyplin bez refleksji i potrzeby, a więc jest bardziej eklektyzmem niż dialogiem między dyscyplinami.

Zdaniem niektórych, mówienie dziś o interdyscyplinarności jest anachronizmem i metodologiczną mrzonką, gdyż mamy do czynienia z płynnością dyscyplinowych granic ${ }^{8}$. Szansą na interdyscyplinarność jest burzenie granic między dyscyplinami, a nie sumowanie wiedzy ${ }^{9}$. Wyrazem tego jest prowadzenie badań ,nad" wybranymi fragmentami otaczającej nas rzeczywistości i ujmowanie ich w perspektywie różnych dyscyplin.

Inni zaś zwracają uwagę na „kryzys idei interdyscyplinarności” i niespełnione oczekiwania w zakresie współpracy różnych nauk oraz integracji wiedzy. Interdyscyplinarność miała być środkiem zaradczym (remedium) na kakofonię języków teoretycznych, a tymczasem jej kryzys przejawia się w zamykaniu we własnych specjalnościach, braku porozumienia i wspólne-

${ }^{5}$ M. Nowak, Pedagogiczny profil nauk o wychowaniu. Studium z odniesieniami do pedagogiki pielegniarstwa, Lublin 2012, s. 253.

6 M. Dudzikowa, Wprowadzenie, ,Rocznik Pedagogiczny” 33 (2010), s. 31-36.

${ }^{7}$ A. Grobler, Interdyscyplinarność, ,Rocznik Pedagogiczny” 33 (2010), s. 37-38.

${ }^{8}$ Zob. K. Majbroda, O nieszczelnych granicach wspótczesnej nauki. Przypadek antropologizowania (się) humanistyki, w: B. Płonka-Syroka, Z. Kaźmierczak (red.), Nauka w kontekście wzorców kultury, Warszawa 2011, s. 150.

9 M. P. Markowski, Efekt inskrypcji. Jacques Derrika i literatura, Bydgoszcz 1997, za: M. Dudzikowa, Sytuacja problematyczna interdyscyplinarności w naukach spolecznych $i$ humanistycznych (z kryzysem w tle), w: A. Chmielewski, M. Dudzikowa, A. Grobler (red.), Interdyscyplinarnie o interdyscyplinarności. Między ideq a praktyka, Kraków 2012, s. 19. 
go języka oraz braku możliwości syntezowania wyników badań ${ }^{10}$, a przeciwstawnie pojawiają się usilne dążenia do zachowania autonomii dyscyplin i subdyscyplin ${ }^{11}$. W efekcie nie udaje się stworzyć pełnego obrazu poznawanego przedmiotu.

Tocząca się dyskusja nad interdyscyplinarnością wskazuje, że jest ona współcześnie wyzwaniem oraz że istnieje potrzeba weryfikacji stanowisk wobec interdyscyplinarności ${ }^{12}$. Z uwagi na przedmiot poznania interdyscyplinarność i intradyscyplinarność jest też bezpośrednio wyzwaniem dla pedagogiki rodziny.

Interdyscyplinarność (międzydyscyplinarność) wskazuje na kooperację, ale i współzależność badań prowadzonych na styku różnych dyscyplin i teorii naukowych. Nie chodzi jedynie o wykorzystanie istniejących zasobów wiedzy, lecz o model pracy zespołowej. Prowadzone badania mają służyć rozwiązaniu określonego problemu badawczego, który należy do klasy problemów interdyscyplinarnych. Zdaniem I. Wallersteina, wiele badań przeprowadzonych byłoby lepiej, gdyby badacze łączyli wiedzę z dwóch lub więcej dyscyplin ${ }^{13}$.

Zasada interdyscyplinarności w pedagogice jest rozwiązaniem na rozbicie pedagogiki na nauki pedagogiczne, co ograniczyłoby pedagogikę do dialogu $\mathrm{w}$ ramach własnych subdyscyplin ${ }^{14}$. Jest wyrazem włączenia się pedagogiki i jej subdyscyplin w dialog nad wychowaniem człowieka w różnych środowiskach jego życia. Wychowanie w rodzinie jako przedmiot poznania implikuje problemy badawcze, których rozwiązanie przekracza możliwości poszczególnych dyscyplin, przebiegają one niejako w poprzek dyscyplin. Podejmowanie problematyki wychowania w rodzinie, zarówno w kontekście historycznym, jak i współczesnym, wymaga dialogu interdyscyplinarnego. Jednocześnie wymaga również współpracy subdyscyplinarnej. Intradyscyplinarność, określana też jako inter-, subdyscyplinarność ${ }^{15}$, ma swoje uzasadnienia $\mathrm{w}$ interakcjach poznawczych i badawczych najpierw w pedagogice (,otwarcie do wewnątrz”), potem w także ramach innych dyscyplin.

${ }^{10}$ R. Nycz, Głos do artykułu Barbary Kaszkowskiej, w: F. Czech, P. Ścigaj, A. Włodarczyk (red.), Szkice o pograniczach nauk, Kraków 2007, za: M. Dudzikowa, Sytuacja, s. 19.

11 Zob. A. Bronk, dz. cyt., s. 47-77.

12 Zob. A. Chmielewski, M. Dudzikowa, A. Grobler (red.), dz. cyt.

${ }^{13}$ I. Wallerstein, Analiza systemów - światów. Wprowadzenie, Warszawa 2007, s. 144 i nn.

${ }^{14}$ M. Nowak, dz. cyt., s. 253.

${ }^{15}$ L. Witkowski, Uwagi o interdyscyplinarności w pedagogice (z perspektywy epistemologii krytycznej), ,Rocznik Pedagogiczny” 33 (2010), s. 57-58. 
Jednocześnie warto nadmienić, że chociaż zauważa się pewnego rodzaju modę na wąskie specjalności, to jednak zamknięcie w ramach specjalizacji jest zamknięciem drogi do interdyscyplinarności.

Szerokie obszary badawcze, problemy interdyscyplinarne i także postawa transgresyjna samych badaczy uzasadniają tworzenie nauk interdyscyplinarnych - jak właśnie nauki o rodzinie - familiologii. Badania interdyscyplinarne wyróżniają się dobrze i jasno określonym problemem badawczym, którego rozwiązanie jest możliwe w dialogu i współpracy dwóch lub kilku nauk. Wykracza to zdecydowanie poza informacyjne i aplikacyjne wykorzystanie wiedzy i teorii naukowych.

Pojęcia poboczne dla interdyscyplinarności to wielodyscyplinarność (multidyscyplinarność), transdyscyplinarność i unidyscyplinarność. Multidyscyplinarność wskazuje ten rodzaj badań, w które zaangażowanych jest wiele dyscyplin nauki, tworzących luźną koalicję dyscyplin o zróżnicowanym pod względem problemów i metod statusie. Ich kompleks problemowy jest niezbyt jasno i precyzyjnie określony, aczkolwiek posiadają one wspólny obszar problemowy i instytucjonalne osadzenie, co zapewnia niezbędny rodzaj integracji (np. kognitywistyka, neuronauka, językoznawstwo) ${ }^{16}$. Samo zestawienie dyscyplin nie tworzy bowiem jeszcze multidyscyplinarności. W ramach multidyscyplinarności może dochodzić do badań interdyscyplinarnych. Transdyscyplinarność oznacza prowadzenie analiz i badań wykraczających poza (ponad) standardowe dyscypliny. Dostarczają one abstrakcyjnych pojęć (modeli, kategorii) z odwołaniem do ich ontologicznego i epistemologicznego wymiaru (np. relacja, system, przedmiot, własność, prawda). Teorie i modele są na tak ogólnym i najwyższym poziomie abstrakcji, że mogą być wykorzystane przez różne dyscypliny, gdyż wykraczają poza poziom konkretności chociażby jednej z nich. Mają one zastosowanie $\mathrm{w}$ uniwersalnym dyskursie nauki $\mathrm{z}$ wykorzystaniem wiedzy mono- $\mathrm{i}$ interdyscyplinarnej ${ }^{17}$. Unidyscyplinarność wskazuje na brak wystarczających powodów intelektualnych dla rozdziału dyscyplin, wszelka praca naukowa powinna być traktowana jako część jednej wspólnej dyscypliny (np. historyczne nauki społeczne $)^{18}$.

Można uznać, że przedrostki ,,inter-”, ,intra-”, ,,multi-”, „trans-”, „uni-” są wyrazem integracyjnych tendencji obecnych w nauce, a także zaintere-

${ }^{16}$ R. Poczobut, Interdyscyplinarność i pojęcia pokrewne, w: A. Chmielewski, M. Dudzikowa, A. Grobler (red.), dz. cyt., s. 41-42.

17 Tamże, s. 58.

${ }^{18}$ I. Wallerstein, dz. cyt., s. 144. 
sowań poznawczych człowieka, wymagających interdyscyplinarnej syntezy. Interdyscyplinarność łączy się z wyjaśnieniem i rozumieniem zjawisk granic dyscyplinowych i wymaga utrzymania metanaukowego poziomu refleksji, gdyż całościowe rozwiązanie problemu interdyscyplinarności dokonuje się na gruncie metodologii i filozofii nauk.

\section{Intradyscyplinarność i interdyscyplinarność a specjalizacja i integracja wiedzy o wychowaniu w rodzinie}

Prowadząc refleksję i rozważania nad interdyscyplinarnością i intradysyplinarnością w pedagogice rodziny, należy mieć na uwadze 1) antropologiczny, ontologiczny i epistemologiczny kontekst, 2) specyfikę przedmiotu poznania oraz 3 ) zagadnienia jedności nauki wraz z problemem integracji i specjalizacji wiedzy.

1. Szczególnie kwestie interdyscyplinarności (w oczywisty sposób także intradyscyplinarności) odnoszą się do zagadnień wyjaśniania struktury bytowej człowieka i jego osobowego istnienia w świecie (kontekst antropologiczny); do określania przedmiotu poznania i istoty rzeczywistości - „natury rzeczy”, a więc wychowania i rodziny (kontekst ontologiczny). Rozumienie wychowania jest bardzo zróżnicowane, odzwierciedleniem tego jest wielość teorii i koncepcji wychowania. Brak w tym względzie uniwersalnego stanowiska. Tylko wysoki poziom ogólności w ujmowaniu wychowania pozwala pokonać bariery czasowe, terytorialne, kulturowe czy światopoglądowe. Obecnie w literaturze przedmiotu pojawia się również wiele interpretacji i sposobów rozumienia rodziny. Wymaga to jednak odrębnych uwag w perspektywie pedagogiki rodziny. Kwestie interdyscyplinarności odnoszą się również znacząco do typu i źródła poznania (kontekst epistemologiczny) z nawiązaniem do empiryzmu, racjonalizmu i metaforyzmu, a więc do filozoficznej tradycji spekulatywno-intuicyjnej i empiryczno-pragmatycznej. Wobec tych zagadnień formułowane są główne problemy metodologiczne pedagogiki rodziny, dotyczące orientacji metodologicznych, strategii badań, możliwości i warunków ich komplementarności, a przede wszystkim konceptualizacji przedmiotu poznania. 
2. Wychowanie w rodzinie jako materialny przedmiot poznania ${ }^{19} \mathrm{z}$ natury jest interdyscyplinarny. Łączy dwie złożone i kluczowe dla egzystencji człowieka rzeczywistości: rzeczywistość rodziny i rze-

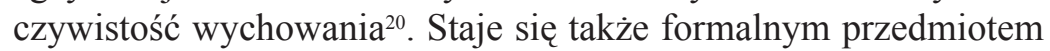
poznania wielu dyscyplin, ujętym z różnych punktów widzenia. Zatem wiedza o wychowaniu $\mathrm{w}$ rodzinie $\mathrm{z}$ uwagi na przedmiot poznania dzieli się na wiedzę ogólną i wieloaspektową (badania nad wychowaniem, rodzina) oraz wiedzę specjalistyczna, jednostkową ${ }^{21}$. To wiedza dyscyplinarna i subdyscyplinarna. Jej rozwój łączy się $\mathrm{z}$ dwoma dążeniami. $Z$ jednej strony to dążenie do otwartości na dorobek innych dyscyplin, $z$ drugiej do zamknięcia, odrębności i wyjątkowości dyscypliny/subdyscypliny ${ }^{22}$.

3. Interdyscyplinarność implikuje tendencje pozornie rozbieżne, lecz $\mathrm{w}$ istocie komplementarne: do integracji wiedzy oraz do specjalizacji wiedzy. Specjalizacja jest wartościowa, o ile sprzyja integracji wiedzy, a więc uzyskaniu bardziej spójnego i całościowego oglądu rzeczywistości. Zdaniem S. Kamińskiego „specjalizacja nie jest cnota, lecz złem koniecznym" "23. Daleko posunięty podział dyscyplinarny i subdyscyplinarny $\mathrm{w}$ nauce może prowadzić do syndromu wieży Babel ${ }^{24}$, braku porozumienia między przedstawicielami różnych nauk i modelu pracy zespołowej, a w efekcie braku spójności wiedzy i niemożności scalania wiedzy. Zgromadzona w wąskich teoriach wiedza jest niewystarczająca dla rozwiązywania problemów złożonych. Integracja przełamuje bariery specjalizacji i jest dążeniem do poszukiwania systemów, ogólnych ujęć, uzyskania wiedzy ogólnej z różnych perspektyw i w różnych kontekstach. Zachodzi wskutek przenikania się nauk szczególnie dzięki dyscyplinom pogranicznym. Integracja jest pośrednim typem jedności

19 A. Bronk, dz. cyt., s. 57.

${ }^{20}$ Szerzej: D. Opozda, Rozwój wiedzy, s.75 i nn.; tenże, Struktura i treść jednostkowej wiedzy o wychowaniu. Studium pedagogiczne wiedzy rodziców i jej korelatów, Lublin 2012, s.69 i nn.

${ }^{21}$ S. Kamiński, Pojecie nauki i klasyfikacja nauk, Lublin 1998, s. 25.

22 E. Tarkowska, Między izolacja a wspótpraca. Socjologia polska wobec innych dyscyplin, w: A. Chmielewski, M. Dudzikowa, A. Grobler (red.), dz. cyt., s. 131.

23 S. Kamiński, dz. cyt., s. 275.

24 J. Mizińska, Człowiek to człowiek. Esej o kulturowych i światopogladowych przesłankach problemu interdyscyplinarności, w: A. Chmielewski, M. Dudzikowa, A. Grobler (red.), dz. cyt., s. 71 . 
nauk i przejawia się w jednorodności i jednolitości dyscyplin naukowych. Po pierwsze, wymaga tych samych kryteriów naukowości (język, metoda - względy formalne). Po drugie, jest to scalanie nauk i ich zwartości celem otrzymania spójnego układu wiedzy dzięki powiązaniom genetycznym (powstanie, rozrost problematyki jednej nauki), obecności systemów wiedzy dla danej nauki bardziej uniwersalnych i reprezentatywnych oraz wzajemnemu dopełnianiu się (głównie w zakresie przedmiotu, zadań i cząstkowego typu poznania - względy pozaformalne $)^{25}$. Założenie o jedności nauki z uwzględnieniem procesu integracji i specjalizacji wiedzy pozwala odpowiedzieć na pytanie: Dlaczego pewne dyscypliny sq dla siebie w uktadzie interdyscyplinarnym? Względy formalne i pozaformalne są pewnego rodzaju kodem, kluczem do mówienia o interdyscyplinarności.

W kontekście powyższych uwag można sformułować pytanie o to, jakie miejsce zajmuje pedagogika rodziny $\mathrm{w}$ procesie specjalizacji i integracji wiedzy o wychowaniu w rodzinie. Problem interdyscyplinarności i intradyscyplinarności w odniesieniu do pedagogiki rodziny jest o tyle bardziej wyraźny, ale i interesujący, że subdyscyplina ta jest nieustannie określana jako in statu nascendi.

\section{Pedagogika rodziny w procesie specjalizacji wiedzy o wychowaniu w rodzinie}

Namysł nad specjalizacją wiedzy o wychowaniu w rodzinie w ramach pedagogiki rodziny i w odniesieniu do inter- i intradyscyplinarności ukierunkowuje na problemy: 1) konceptualizacji przedmiotu w pedagogice rodziny; 2) zmian w przedmiocie poznania; oraz 3 ) tworzenia zasobów wiedzy pedagogicznej o wychowaniu w rodzinie. Zagadnienia te szerzej omówiłam w innym miejscu, więc tylko sygnalnie warto zwrócić uwagę na niektóre z nich ${ }^{26}$.

Przedmiot poznania $\mathrm{w}$ pedagogice rodziny rozumiany może być $\mathrm{w}$ dwojaki sposób ${ }^{27}$. Jako przedmiot badania w pedagogice zawierający ogólny

${ }^{25}$ S. Kamiński, dz. cyt., s. 277-280.

${ }^{26}$ Zob. D. Opozda, Rozwój wiedzy.

${ }_{27}$ Por. T. Bauman, Komplikacje i dylematy przy określaniu przedmiotu badań pedagogicznych, w: K. Rubacha, Konceptualizacje przedmiotu badań pedagogiki, Kraków 2008, s. $58-64$. 
ogląd, odwołujący się do wielkich teorii ujęć metasystemowych i podejść uniwersalnych ${ }^{28}$ (np. funkcja wychowawcza rodziny, kultura pedagogiczna, rozumienie rodziny, dysfunkcjonalność rodziny) oraz jako przedmiot w badaniach pedagogicznych. W drugiej sytuacji chodzi o odwołanie się i rozwój wąskich teorii, tworzenie modeli zjawisk, badania wycinkowe, których wartość naukowa wyraża się w praktycznych zastosowaniach (np. współpraca rodziny i szkoły, autorytet rodzicielski).

Zmiany w przedmiocie łączą się z obecnością zjawisk z natury interdyscyplinarnych. $W$ ramach pedagogiki rodziny podejmowane są badania nad zjawiskami wymagającymi poznania różnych subdyscyplin i dyscyplin, lokalizowanych w ,poprzek dyscyplin i uświęconych tradycją obszarów badań" ${ }^{29}$, opisywanych na styku różnych teorii (np. tożsamość rodzica, wychowanie w rodzinie a rozwój i kształtowanie tożsamości płciowej, postaw altruistycznych, wartości). Zjawiska te i problemy badawcze wybiegają poza dotychczasowe granice poznania nie tylko pedagogicznego, ale $\mathrm{i}$ innych dyscyplin. Ponadto, jak zauważa Teresa Bauman, współczesnych badaczy charakteryzuje postawa transgresyjna, wyrażająca się wykraczaniem poza teren dotychczasowych eksploracji badawczych ${ }^{30}$.

Badanie wąskich zjawisk, a co za tym idzie tworzenie zasobów wiedzy pedagogicznej, jest dążeniem do umiejscawiania wąskiej problematyki wychowania $\mathrm{w}$ rodzinie $\mathrm{w}$ subdyscyplinie. To eksponowanie wiedzy centralnej dla subdyscypliny, wiedzy o węższym zakresie, (,rdzennej”) konstruowanej $\mathrm{w}$ badaniach pedagogicznych, chociaż $\mathrm{w}$ dialogu $\mathrm{z}$ uznanymi teoriami i koncepcjami. Rozwój subdyscyplinarny nie byłby możliwy i użyteczny, gdyby pedagogika rodziny nie była w relacji z inną wiedzą. Daje to możliwość włączenia się w dialog efektów własnych badań pedagogicznych nad rodziną i gwarantuje rozwój subdyscyplinarny, a także dyscyplinarny.

Chociaż więc zauważa się, że podzielenie świata na drobne wycinki (przedmiot $\mathrm{w}$ badaniach pedagogicznych) nie sprzyja rozwojowi, zwłaszcza gdy granice sub- i dyscyplinarne są sztywne i nieelastyczne, to jednak podkreślić trzeba, że sztuką specjalizacji jest „zobaczenie” (poznawanie) fragmentu większej całości, jaką jest wychowanie w rodzinie. Specjalizacja, w dobrym tego słowa znaczeniu, oznacza umiejętność rozumienia wąskich zjawisk w szerszym kontekście.

${ }_{28}$ Por. P. Oleś, Interdyscyplinarność - wyzwanie i konieczność, „Rocznik Pedagogiczny” 33 (2010), s. 41-49.

${ }^{29}$ M. Dudzikowa, Wprowadzenie, s. 32.

${ }^{30}$ T. Bauman, dz. cyt., s. 58. 


\section{Pedagogika rodziny $w$ procesie integracji wiedzy o wychowaniu w rodzinie - dialog intradyscyplinarny i interdyscyplinarny}

Subdyscyplinarną funkcją pedagogiki rodziny jest integrowanie dwóch rodzajów wiedzy o wychowaniu w rodzinie: wiedzy pedagogicznej i wiedzy pochodzącej z innych dyscyplin, a obecnej w pedagogice ${ }^{31}$. Zapewnia to rozwój dyscyplinarny i interdyscyplinarny, a przede wszystkim bardziej kompletny opis zjawisk związanych z wychowaniem w rodzinie. Oba rodzaje wiedzy są użyteczne w poznaniu pedagogicznym i w praktycznej działalności.

Proces integracji wiedzy o wychowaniu w rodzinie w pedagogice rodziny oznacza udział tej subdyscypliny w dialogu intradyscyplinarnym i otwartość subdyscyplinarną. Zadaniem pedagogiki rodziny jest łączenie całego dorobku, wypracowanego przez pedagogikę jako dyscyplinę nauki, dotyczącego wychowania w rodzinie. Wszelkie próby systematyzacji, porządkowania i tworzenia wiedzy są tego wyrazem. Dialog pedagogiki rodziny z innymi subdyscyplinami, dokonujący się wewnątrz dyscypliny, można ująć w układzie wertykalnym i horyzontalnym. Układ wertykalny określa historyczny rozwój i narastanie wiedzy o rodzinie w pedagogice oraz wiąże dotychczas wypracowaną wiedzę pedagogiczną przykładowo przez takie subdyscypliny, jak historia wychowania i opieki, filozofia wychowania, pedagogika społeczna, opiekuńcza, resocjalizacyjna czy specjalna. Zadaniem pedagogiki rodziny jest scalanie wiedzy o wychowaniu w rodzinie i ujmowanie ewolucji zjawisk $\mathrm{w}$ ich dynamice i transformacjach $\mathrm{w}$ aspekcie historycznym, temporalnym (np. zmiany w stylach wychowania w rodzinie, autorytetu i władzy rodzicielskiej, celów wychowania). Układ horyzontalny oznacza współpracę i dialog z innymi subdyscyplinami nad aktualnymi zjawiskami i problemami wychowania w rodzinie (np. wychowanie w rodzinie dzieci z niepełnosprawnością, czynnik rodzinny w niedostosowaniu społecznym).

Udział pedagogiki rodziny $\mathrm{w}$ dialogu interdyscyplinarnym oznacza dopełnianie jedności wiedzy familiologicznej o człowieku, o rodzinie i o wychowaniu przez dostarczanie wiedzy pedagogicznej. Pedagogika rodziny bierze udział w tworzeniu spójnego układu wiedzy i scalaniu nauk,

${ }^{31}$ S. Palka, Wiedza w pedagogice $i$ wiedza pedagogiczna, w: J. Piekarski, D. Urbaniak-Zając, K. J. Szmidt (red.), Metodologiczne problemy tworzenia wiedzy w pedagogice. Oblicza akademickiej praktyki, Kraków 2010, s. 17. 
uwzględniając ich jednorodność (język i metoda) oraz jednolitość. Dialog ten jest uzasadniony interdyscyplinarnym przedmiotem poznania, powiązaniami genetycznymi z innymi dyscyplinami i obecnością uniwersalnych systemów wiedzy (np. pojęcia: środowiska, systemu). Pedagogika rodziny posiada własny kontekst interdyscyplinarny. Tworzą go w znacznej mierze antropologia, socjologia i psychologia. Pedagogika rodziny między innymi: 1) korzysta $\mathrm{z}$ udostępnionej przez antropologię wiedzy o tym, kim jest człowiek i jak przyjęte założenia filozoficzne określają miejsce jego egzystencji w rodzinie; 2) odwołuje się do socjologicznych analiz właściwości makrośrodowiska rodziny oraz społeczno-kulturowych uwarunkowań zmian w modelach życia małżeńsko-rodzinnego; 3) uwzględnia psychologiczny ogląd życia małżeńsko-rodzinnego, mechanizmów wychowawczych oraz prawidłowości rozwoju ontogenetycznego (dzieci, młodzieży i dorosłych), stanowiących istotne tło przebiegu procesu wychowania $\mathrm{w}$ rodzinie.

$\mathrm{W}$ pedagogice rodziny specjalizacja i integracja, rozumiane jako procesy komplementarne, pozwalają lepiej zrozumieć intradyscyplinarność i interdyscyplinarność pedagogicznej wiedzy o wychowaniu w rodzinie. Pozwalają też sformułować wniosek, że narastanie wiedzy o rzeczywistości wychowania w rodzinie nie gwarantuje zrozumienia i skutecznego działania w tej rzeczywistości, dopiero podjęty dialog między subdyscyplinami i dyscyplinami umożliwia bardziej kompletne jej wyjaśnianie i interpretację.

\section{Interdyscyplinarność - wyzwanie i konieczność w pedagogice rodziny}

W podsumowaniu powyższej refleksji można sformułować pytanie, dlaczego intradyscyplinarność, a szczególnie interdyscyplinarność, jest wymogiem w uprawianiu pedagogiki rodziny.

Intradyscyplinarność jest oczywistym faktem w odniesieniu do pedagogiki rodziny, natomiast interdyscyplinarność jest wyzwaniem i koniecznością w opisie, wyjaśnianiu i rozumieniu rzeczywistości wychowania w rodzinie oraz w konstruowaniu o niej pedagogicznej wiedzy. Dialog interdyscyplinarny jest uzasadniony i potrzebny, jak sądzę, ze względu na: 1) szeroki i złożony przedmiot poznania, 2) modele relacji poznawczych w pedagogice, 3) możliwość konfrontacji efektów badań i wiedzy naukowej, 4) względy praktyczne.

Przedmiot poznania pedagogiki rodziny ma naturę interdyscyplinarna, wymaga płynności granic dyscyplinarnych. Implikuje zjawiska, których sub- 
dyscyplina (de facto jakakolwiek) nie jest w stanie opisać i zinterpretować samodzielnie, gdyż brak zadowalających teorii całościowo i samodzielnie je wyjaśniających. Ich natura wymaga konfrontacji i odwołania się do wiedzy innych dyscyplin. W związku z tym należy podkreślić, że istnieje potrzeba prowadzenia badań dla wychowania i nad wychowaniem. Koniecznością wręcz jest unikanie hermetyczności i zamknięcia subdyscyplinarnego, między innymi poprzez postawę transgresyjną samych badaczy i poszerzanie przedmiotu poznania przez całościowe, kompletne badanie zjawisk, które wykraczaja poza dyscyplinarne ramy.

Interdyscyplinarność jest wymogiem w pedagogice rodziny ze względu na obecne w pedagogice w ogóle modele relacji poznawczych. Naukowa wiedza pedagogiczna jest warunkowana elementami teoretycznej wiedzy innych nauk, jest czynnikiem warunkującym wiedzę innych nauk oraz jest komplementarna wobec tejże wiedzy ${ }^{32}$. Uprawianie dyscypliny nauki, a więc również pedagogiki rodziny, zakłada wiedzę towarzyszącą z zakresu innych dyscyplin ${ }^{33}$. Nauka o wychowaniu w rodzinie jest interdyscyplinarna, ale jednocześnie nie oznacza to jeszcze, że każde badania prowadzone w pedagogice rodziny takie są lub muszą takimi być.

Jedność nauki warunkowana pozostawaniem dyscyplin wiedzy w formalnych i pozaformalnych powiązaniach umożliwia także odwołanie do innych nauk w poznawaniu danej rzeczywistości. Zasada interdyscyplinarności w pedagogice rodziny jest zatem wyzwaniem i podstawą do konfrontacji wiedzy naukowej i weryfikacji rezultatów badań, wniosków i wyprowadzanych twierdzeń.

Kwestie interdyscyplinarności $\mathrm{w}$ pedagogice rodziny ukierunkowują jeszcze na względy praktyczne, związane z kształceniem przyszłych pedagogów i z praktyką pedagogiczną. Interdyscyplinarność stawia wymagania co do kształcenia studentów, nabywania przez nich wiedzy, umiejętności i kompetencji potrzebnych do pracy z rodziną. Chodzi o takie kształcenie, które uczy nie tylko specjalistycznego, wąskiego myślenia, zagrożonego wycinkowością i fragmentaryzmem, ale uczy myślenia interdyscyplinarnego w rozumieniu zjawisk pedagogicznych, udostępnia pełniejszy ogląd zjawisk i zmusza do „dopuszczania” i uwzględniania (a przynajmniej zostawienia marginesu) kontekstu wiedzy innych nauk - kontekstu interdyscyplinarnego. W praktyce edukacyjnej umożliwia to efektywniejszą pracę pedagogów

\footnotetext{
32 Tamże, s. 20 i nn.

33 A. Grobler, dz. cyt., s. 38-39.
} 
w zespołach interdyscyplinarnych w zakresie działań związanych z diagnoza, poradnictwem, profilaktyką i terapią pedagogiczna.

Wymóg interdyscyplinarności i intradyscyplinarności w pedagogice rodziny pozwala, jak sądzę, pełniej zobaczyć problem rozwoju pedagogicznej wiedzy o wychowaniu w rodzinie. Wiedzy dynamicznej, będącej dialogiem prowadzonym wewnątrz dyscypliny i poza nią. Dążenie do autonomii i specjalistycznego zamknięcia, jak określił to Th. Adorno, skazuje (sub)dyscyplinę na barbarzyńskie status quo. Można więc sformułować tezę, że in statu nascendi pedagogiki rodziny jest raczej jej przywilejem, niż jarzmem.

\section{Interdisciplinarity and Intradisciplinarity in Family Pedagogy (Summary)}

The article deals with the problem of the interdisciplinarity and the intradisciplinarity in family pedagogy. This text refers to the methodological issues of family pedagogy, particularly, its subject of study. The problem of specialization and integration of knowledge about the upbringing in the family is presented in the article. The requirement of the interdisciplinarity and the intradisciplinarity in family pedagogy is substantially connected with the development of the pedagogical knowledge about the upbringing in the family - the dynamic knowledge, which is the result of the dialogue that is sustained inside and outside the discipline. The following question may be raised: is in statu nascendi of the family pedagogy rather its privilege or burden?

Keywords: interdisciplinarity, intradisciplinarity, family pedagogy, knowledge, upbringing, family

\section{Interdyscyplinarność i intradyscyplinarnosć w pedagogice rodziny (Streszczenie)}

W artykule podjęta została problematyka interdyscyplinarności i intradyscyplinarności w pedagogice rodziny. Tekst nawiązuje do metodologicznych zagadnień pedagogiki rodziny, a szczególnie jej przedmiotu badań. Przedstawia problem specjalizacji i integracji wiedzy o wychowaniu w rodzinie. Wymóg interdyscyplinarności i intradyscyplinarności w pedagogice rodziny istotnie łączy się z rozwojem pedagogicznej wiedzy o wychowaniu w rodzinie. Wiedzy dynamicznej, która jest 
efektem dialogu prowadzonego wewnątrz dyscypliny i poza nią. Można sformułować pytanie, czy in statu nascendi pedagogiki rodziny jest raczej jej przywilejem czy jarzmem?

Słowa kluczowe: interdyscyplinarność, intradyscyplinarność, pedagogika rodziny, wiedza wychowanie, rodzina 